\title{
Review of the Economic Influence of Mastitis in Ruminants
}

\author{
D.O.I - 10.51201/Jusst12534
}

http://doi.org/10.51201/Jusst12534

Amanee M. Radhy, Saba Thamer Mosa

Department of Internal and Preventive Veterinary Medicine, College of Veterinary Medicine, Baghdad University, Iraq.

\begin{abstract}
Summary
Mastitis is usually acommon and prevalent disease that is individual of the furthermostcollective and expensive diseases in the dairy manufacturing. In addition, breast milk directly affects the quality and quality of milk, with the technical properties and high quality present in milk, and indirectly the quality of milk. Management is considered one of the most effective means of controlling mastitis. Given the complex, multifunctional nature of mastitis, management encompasses a wide range of activities, among others, disease (clinical or semi-classic form), treatment of dry cows, prevention of transmission.
\end{abstract}

By improving the immune system of an animal there is a large number of literature on the treatment of mastitis, and on the economics of mastitis management and the treatment of mastitis. Economic figures differ between countries and even between regions within a country. In addition, the changes that occur in the results of the quality of milk and changes in marketing conditions. To make matters more complicated lead to large accounts of these results over time and changes between studies and there are many differences between the losses known recorded.

These differences and inconsistencies are not only because of differences between performance and regions, but also to the different population levels used in the analysis. The result was that the research revealed these differences, contradictions and changes, making it difficult to reach a clear general deduction about the economics of treating mastitis.

\section{Milk manufacture losses}

The commercialsignificances of mastitis (clinical or quasi-clinical) are because of the cost of the treatments used, reduced production, bed bugs, changes in production quality, and other common diseases. The related costs can be divided into the following factors: Medicines to reduce wasted milk production, product quality, veterinary services and administration. The relative prices of these influences vary according to different countries and regions and to manage the herd or field itself $(1,2)$.

The significant losses in milk production are from both clinical and subclinical mastitis, and most of the estimated production loss is due to clinical mastitis (3). The large and sharp decline in production due to sub-mammals in general constitutes a direct linear logarithmic relationship between somatic cell counts (SCs). Additionally, St. Rose et al. (4). Untreated mastitis and uteritis have been found to affect improved milk production. Thus, the direct relationship may lead to a reduction in manufacture losses because of clinical mastitis.

The systems differ in the ways of pushing the milk (payments depend on kilograms of milk components such as fat, protein, or kilograms of milk). In addition, the calculation of economic losses due to a significant reduction in milk production may differ between the quota system and the non-quota system. (5-7).

In a dairy system where farmers do not have a quota of milk, the production capacity of the farm is the number of dairy cows on the farm. The number of dairy cows present in the farm can be determined by the size or area of the barn, the number of workers present, the fodder available, or the available capital.The decrease in milk production for each cow present in the farm due to mastitis, a small amount of milk will be transported to the factory and the amount of pure milk returned in the field will also be reduced. Sometimes there is some stock of concentrated feed, as when the cows are fed in terms of milk 
manufacture, it may facilitate the farmer to provide feed (concentration), which reduces other or secondary costs (9). In rationing systems, the calculation of economic losses to reduce the amount of milk manufacture develops other complex. $(8,9)$.

Imports from the sale of milk and its derivatives are of great importance and the goal of the farmer is to yield milk in large quantities as professionally as likely, with the decrease in milk manufacture and quality, the breeder has several options, based on the law of the system of maximum utilization of cows: more milk must be given to feed the cows. In this case, the cost of economic loss is intended more as the added price of milking other cows. In addition, the difficulty of estimating these costs includes costs for feed, veterinary services, and medicines. (10).

Cow's milk production can be increased and its quality improved by working with a better feeding system. The cost is related to the large amount of feed required to achieve the required level of production. High milk manufactureeach cow can result in health disorders (51). Due to mastitis and the associated decrease in the amount of milk production, revenue from milk sales will decrease. However, imports may result from requiring less feed and renting part of the milk will result in significant losses.(11,13).

\section{Drugs}

Medicines may differ according to the outcome between countries according to the law and the infrastructure of the country, and the drugs needed treating infected cows, which is the reason affecting the commercial cost.

\section{Discarded milk}

Thus, the commercial loss of $100 \mathrm{~kg}$ of powdered milk is greater than the decrease in production by 100 $\mathrm{kg}$. Although not recommended then a veterinary point of view, abandoned milk is often fed to 21 calves instead of imitation milk, which raises the price of this milk. (14).

The commercial loss from discarded milk is equal to the loss due to reduced milk manufacture. Though, there is a change: the missed milk is actually formedin cows, which resources that the cost of this quantity of milk must be taken into account in the calculation.

\section{Veterinary services}

In addition to dispensing medications, a veterinarian may have to apply diagnosing (clinical) mastitis (15). Veterinary services can be obligatory for every case of (clinical) mastitis, if necessary by general law, or providing by the farmer only upon request.

\section{Work}

If outside work is done, it is easy to calculate the cost of the animation time period for mastitis (hourly wage). Labor costs are difficult to explain. The opportunity cost of labor may vary from another farm. If the farmer runs out of free time, the opportunity cost is zero. Customers, the low cost abroad because of the low cost of these activities. $(16,17)$.

\section{Product quality}

This influence contains the quality of meat and milk. T-terrier does not affect meat quality, but mastitis does affect milk quality (18-20). Some of these changes lead to adequate treatment of the milk and other products may have less valuable properties $(21,22)$. It is difficult to calculate the associated economic losses, just as the direct impact of this economic loss is expected in drought regions.

The only level of milk quality that has a straight response that can be estimated is fever resulting from reflux, alkaline red sugar, bacterial and / or physiological factors in mammals in cow. Therefore, in 
most countries, there are limits. TEMI bay (propulsion system or metaplastic system) due to the number of milk bacteria and somatic cells with large macrophages.(23).

Inflammatory conditions can cause an increase in the severity of $\mathrm{HCH}$ whose laboratory results are an important substance against milk propulsion system residues for economic consequences (24) as well as the number of infections and bacteria. Although mastitis itself does not affect growth inhibitors, antibiotics are used in the treatment of hyperplasia. Dissimilar countries and dairy that used different regulations on antibiotic residue, however the commercialsignificances are safe.(25-29).

The difference in the results is not only explained by the differences between performance and regions, but also to the standard of living of the different populations used in raising cows. The results were that the research revealed these differences and changes, which makes it difficult to reach an accurate, general and clear conclusion about the costs of treating mastitis. $(30,31)$.

\section{Materials and investment}

The management of mastitis by using materials and components that cost a lot of money and these supplies can be unprecedented aimed at example, antiseptics and medicines can be considered as exactkinds of renewable materials or non-renewable materials such as the new milking parlor.(32-37).

The purchase of non-renewable materials has a far-reaching effect and the purchase cost is divided into different years according to the duration of the depreciation. In addition, given that the capital is linked to such purchases, interest rates must also be calculated and in the end most of these nonrenewable materials require maintenance and this also generates other additional prices.

\section{Other diseases}

Deficiency in milk supply, shortage of medicines, veterinary services, product quality, ingredients, investment, diagnosis and clinical and economic outcomes of all these cows. In addition to these direct costs, mastitis-infected cows can be considered a permanent basis of contaminationbecause of the elimination of bacteria. There may likewise be an association among mastitis and extra livestock diseases.

When the danger of developing further diseases increases due to mastitis, the commercial loss of additional conditions caused by mastitis due to one disease can be considered as economic loss, this damage is the difficulty of family interactions between different diseases. Is determined by reason of and this is difficult to do.(38-39).

\section{References}

I. Al lore HG and Erb FIN. Partial budget of the discounted annual benefits of mastitis control strategies. Journal of Dairy Science 1998; 81: 2280-2292.

1. Al lore HG and Erb HN. Approaches to modeling intramammary gland infections in cattle. Preventive Veterinary Medicine 1999; 39: 279-293.

2. Bartlett PC, Miller GY, Anderson CR and Kirk JH. Milk production and somatic cell count in Michigan dairy herds. Journal of Dairy Science 1990; 73: 2794-2800.

3. Beek HS, Wise WS and Dodd FH. Costs benefit analysis of bovine mastitis in the UK. Journal of Dairy Research 1992; 59: 449-460.

4. Bennett $R$, Christiansen $K$ and Clifton-Hadley $R$. Preliminary estimates of the direct costs associated with endemic diseases of livestock in Great Britain. Preventive Veterinary Medicine 1999; 39: 155-171.

5. Berry EA, Hogeveen and Hillerton JE. Decision tree analysis to evaluate dry cow strategies under UK conditions. Journal of Dairy Research 2004; 71: 409-418. 
6. De Graves FJ and Fetrow J. Partial budget analysis of vaccinating cattle against coliform mastitis with an Escherichia colt 15 vaccine. Journal of the American Veterinary Medicine Association 1991; 199: 451-455.

7. Dekkers JCM, Van Erp T and Schukken YH. Economic benefits of reducing somatic cell count under the milk quality program of Ontario. Journal of Dairy Science 1996; 79: 396-401.

8. Erskine RI and Eberhart R.J. Herd benefit-to-cost ratio and effects of a bovine mastitis control program that includes blitz treatment of Streptococcus agalactiae. Journal of the American Veterinary Medical Association 1990; 196: 1230-1235.

9. Fourichon C, Seegers H, Beaudeau F, Verfaille L and Bareille N. Health-control costs in dairy farming systems in western France. Livestock Production Science 2001; 68: 141-156.

10. Grohn YT, Raja la-Schultz PJ, Al lore HG, Delorenzo MA, Hertl JA and Galligan DT. Optimizing replacement of dairy cows: modeling the effects of diseases. Preventive Veterinary Medicine 2003; 61: 27-43.

11. Grohn YT, Wilson DJ, Gonzalez RN, Herd JA, Schulte H, Bennett G and Schukken YH. Effect of pathogen-specific clinical mastitis on milk yield in dairy cows. Journal of Dairy Science 2004; 87: 3358-3374.

12. Hall DC, Ehui SK and Shapiro BI. Economic analysis of the impact of adopting herd health control programs on smallholder dairy farms in Central Thailand. Agricultural Economics 2004; 31: 335-342.

13. Hogeveen $H$ and Lankveld JMG. Economics of milk quality some starting points for discussion. In: Proceedings of the workshop definition of normal and abnormal milk at the time of milking, Foulum, Denmark 2002. Edited by M.D. Rasmussen. pp. 81-89.

14. Hortet $P$ and Seegers $H$. Loss in milk yield and related composition changes resulting from clinical mastitis in dairy cows. Preventive Veterinary Medicine 1998; 37: 1-20.

15. Houben EHP, Huirne RBM, Dijkhuizen AA and Kristensen AR. Optimal replacement of mastitis cows determined by a hierarchic Markov process. Journal of Dairy Science 1994; 77: 29752993.

16. Huijps $K$ and Hogeveen II. Economic evaluation of dry cow therapy. Journal of Dairy Science 2007; 90: 1225-1234.

17. Kossaibati MA and Esslemont RJ. The costs of production diseases in dairy herds in England. Veterinary Journal 1997; 154: 41-51.

18. Lehenbauer TW and Oltjen JW. Dairy cows culling strategies: making economic culling decisions. Journal of Dairy Science 1998; 81: 264-271.

19. Losinger WC. Economic impacts of reduced milk production associated with an increase in bulktank somatic cell count on US dairies. Journal of the American Veterinary Medical Association 2005; 226: 1652-1658.

20. Ma Y, Ryan C, Barbano DM, Galton DM, Rudan MA and Boor KJ. Effects of somatic cell count on quality and shelf-life of pasteurized fluid milk. Journal of Dairy Science 2000; 83: 264-274.

21. Miller GY and Bertlett PC. Economic effects of mastitis prevention strategies for dairy producers. Journal of the American Veterinary Medical Association 1991; 198: 227-231.

22. Miller GY, Bertlett PC, Lance SE, Anderson J and Heider LE. Costs of clinical mastitis and mastitis prevention in dairy herds. Journal of the American Veterinary Medicical Association 1993; 8: 1230-1236.

23. Miller RH, Paape MJ, Fulton LA and Schultz MM. The relationship of somatic cell count to milk yield for Holstein heifers after first calving. Journal of Dairy Science 1993; 76: 728-733.

24. Oliver SP, Lewis MJ, Gillespie BE, Dowlen HH, Jaenicke EC and Roberts RK. Prepartum antibiotic treatment of heifers: Milk production, milk quality and economic benefit. Journal of Dairy Science 2003; 86: H . . - 31 1187-1193.

25. Osterás 0, Hogeveen H, Singh DK and Leslie KE. Economic consequences of mastitis. Bulletin of the International Dairy Federation 394/2005. IDF, Bruxelles, Belgium. 2005. 
26. Peeler EJ, Otte MJ and Esslemont RJ. Inter-relationships of periparturient diseases in dairy cows. Veterinary Record 1994; 5: 129-132.

27. Pyorala $S$ and Mattila T. Inflammatory changes during experimental bovine mastitis induced by Staphylococcus aureus, Streptococcus dysgalactiae and Streptococcus uberis. Journal of Veterinary Medicine. Series A 1987; 34: 574-581. 38. Reinsch N and Dempfle L. Investigations on functional traits in Simmental: 1. Treatment costs for ten different diseases. Journal of Animal Breeding and Genetics 1997; 114: 407-417.

28. Santos MV, Ma Y and Barbano DM. Effect of somatic cell count on proteolysis and lipolysis in pasteurized fluid milk during shelf-life storage. Journal of Dairy Science 2003; 86: 2491-2503.

29. Schukken YH, Weersink AJ, Leslie KE and Martin SW. Dynamics and regulation of bulk milk somatic cell counts. Canadian Journal of Veterinary Research 1993; 57: 131.

30. Seegers H, Fourichon $C$ and Beaudeau F. Production effects related to mastitis and mastitis economics in dairy cattle herds. Veterinary Research 2003; 24: 475-491.

31. Shim EH, Shanks RD and Morin DE. Milk loss and treatment costs associated with two treatment protocols for clinical mastitis in dairy cows. Journal of Dairy Science 2004; 87: 2702-2708.

32. St.Rose SG, Swinkels JM, Kremer WDJ, Kruitwagen CLJJ and Zadoks RN. Effect of penethamatehydriodide treatment on bacteriological cure, somatic cell count and milk production of cows and quarters with chronic subclinical Streptococcus uberis or Streptococcus dysgalactiae infections. Journal of Dairy Research 2003; 70: 387-394.

33. Swinkels JM, Rooijendijk JGA, Zadoks RN and Hogeveen H. Use of partial budgeting to determine the economic benefits of antibiotic treatment of chronic sub clinical mastitis caused by Streptococcus uberis or Streptococcus dysgalactiae. Journal of Dairy Research 2005; 72: 75-85.

34. Swinkels JM, Hogeveen H and Zadoks RN. A partial budget model to estimate economic benefits of lactational treatment of subclinical Staphylococcus aureus mastitis. Journal of Dairy Science 2005; 88: 4273-4287.

35. Van Eenennaam AL, Gardner IA, Holmes J, Perani L, Anderson RJ, Cullor JS and Guterbock WM. Financial analysis of alternative treatments for clinical mastitis associated with environmental pathogens. Journal of Dairy Science 1995; 87: 2086-2095.

36. Windig JJ, Calus MPL, De Jong $G$ and Veerkamp RF. The association between somatic cell count patterns and milk production prior to mastitis. Livestock Production Science 2005; 96: 291-299.

37. Yalcin C, Stott AW, Logue DN and Gunn J. The econo- mic impact of mastitis-control procedures used in Scottish dairy herds with high bulk-tank somatic cell count. Preventive Veterinary Medicine 1999; 41: 135-149.

38. Yalcin C and Stott AW. Dynamic programming to investigate financial impacts of mastitis control decisions in milk production systems. Journal of Dairy Science 2000; 67: 515-528.

39. Zadoks RN, Allore HG, Hagenaars TJ, Barkema HW and Schukken YH. A mathematical model of Staphylococcus aureus control in dairy herds. Epidemiology and Infection 2002; 129: 397-416. 